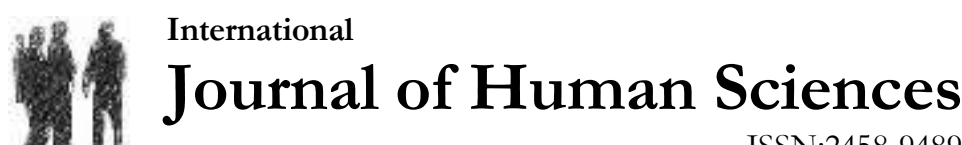 \\ ISSN:2458-9489
}

Volume 14 Issue 4 Year: 2017

\section{Self-regulated learning in nursing: A study from a health education course}

\author{
Ayla Keçeci ${ }^{1}$
}

\begin{abstract}
Background: Self-regulation related to cognition and behaviour is an important factor in learning and academic achievement. Self-regulated learning is defined as the process of learning in which students activate and develop their own cognition, motivation and behaviour through selfregulatory processes.
\end{abstract}

Objectives: The aim of this study was to determine the self-regulation skills of nursing students on a health education course in a state university in Turkey.

Methods: The study sample consisted of 110 students who attended the class on the day of the survey and agreed to participate in the study. Data were collected with the Turkish version of the 'Motivated Strategies for Learning Questionnaire', which was adapted by Büyüköztürk et al. (2004). Data were analyzed using descriptive statistics such as frequency, percentage and mean, as well as the Mann-Whitney $\mathrm{U}$ test, $\mathrm{t}$-test and analysis of variance (ANOVA).

Results: The results showed that the participants were motivated by external factors, using the elaboration strategy more frequently than other learning strategies. Second- and third-year students had various motivational levels and preferred different types of learning strategies, and those students who had more positive perceptions of the school, the course and the instructor evinced higher levels of internal responsibility and benefited from learning strategies more frequently.

Conclusion: Nursing students were found to be predominantly motivated by extrinsic factors and preferred the elaboration learning strategy.

Keywords: Self-regulated learning; motivated strategies for learning; learning strategies; nursing students; nursing; nursing education.

\section{INTRODUCTION}

Self-regulation behaviour related to cognition and behaviour plays a key role in learning and academic achievement (Pintrich and Groot 1990). Self-regulated learning is defined as the process of learning in which students construct their own cognition, motivation and behaviour through self-regulatory processes (Altun and Erden 2006). As a process, self-regulated learning is one in which individuals plan, control and evaluate their learning objectives, using a variety of strategies and resources in the light of their own previous learning experiences (Sarl and Akınoğlu 2009; Song and Hill 2007). In other words, it is the ability to learn by organizing feelings, thoughts and behaviours appropriately (Zumbrunn, Tadlock and Roberts 2011).

\footnotetext{
${ }^{1}$ Assoc. Prof. Dr., Duzce University, Health Sciences Faculty, Nursing Department, aylakececi@gmail.com
} 
There are several models of self-regulated learning, the most significant being the models proposed by Zimmerman, Pintrich and Winne (Sar1 and Akınoğlu 2009). Zimmerman's selfregulation model consists of forethought, performance and self-reflection phases. According to Pintrich's model, self-regulatory processes consist of planning, monitoring, control and reflection phases and self-regulatory activities take place in cognitive, motivational, behavioural and contextual domains (Cleary and Zimmerman 2004; Montolvo and Torres 2004; Pintrich and Groot 1990; Vural 2011; Zimmerman 1990; Sardareh, Saad and Boroomand 2012). Winne's model consists of stages of task definition, goal setting and planning, enacting tactics and reflection (Sar1 and Akınoğlu 2009). All these models are based on the notion that self-regulatory behaviours help learners acquire strategies to shape lifelong learning. Thus, self-regulatory learning is essentially composed of cognitive strategies focusing on learning, recalling and comprehending a certain task, the desire to receive feedback regarding the efficacy of learning and motivation (Cleary and Zimmerman 2004; Pintrich and Groot 1990; Vural 2011; Zimmerman 1990).

Students with self-regulatory skills are distinguished from their peers by their proactive competence and self-motivation skills and their tendency to claim a higher level of responsibility for their own learning (Zumbrunn, Tadlock and Roberts 2011). Research suggests that students with self-regulatory skills are likely to have qualities such as a higher level of motivation and the ability to control their cognition and behaviours in line with their goals, to manage time efficiently, to choose appropriate learning strategies for their learning objectives and to actively cope with problems (Sar1 and Akınoğlu 2009; Sardareh, Saad and Boroomand 2012).

In the light of these informations, research was planned to investigate nursing students' selfregulation skills and contributing other factors to them. The Health Education course originally started to be offered in the second year, thanks to a curricular revision in 2013, and students who had been engaged in the previous version of the curriculum took this course in their third year of study as well. Therefore, this study included students in different years of their education who attended the course in the same term. Both the student groups were given two theoretical and two practical lessons in a week, amounting to 28 theoretical and 28 practical sessions in total. For the practical lessons, the students were asked to choose a relevant topic, prepare an educational learning resource on the topic and make a class presentation.

\section{MATERIALS AND METHODS}

Aim: The aim of this study was to determine the self-regulation skills of nursing students on a Health Education course in a state university in Turkey.

Population and Sample: The study population included 140 students in their second and third year of study who were enrolled in the Health Education course. The study sample consisted of 110 students who were present in the lesson on the survey day and who agreed to participate in the study.

Data Collection Tools: Data were collected using the Motivated Strategies for Learning Questionnaire developed by Pintrich et al. (1991) and adapted for use in the Turkish culture by Büyüköztürk et al. (2004). The theoretical framework of the motivation and learning strategies sections of the Motivated Strategies for Learning Questionnaire (MSLQ) can be summarized as follows. 
Keçeci, A. (2017). Self-regulated learning in nursing: A study from a health education course. Journal of Human Sciences, 14(4), 3830-3842. doi:10.14687/jhs.v14i4.4415

Table 1. Motivation Scale

\begin{tabular}{|l|l|l|}
\hline Components & Factors & \\
\hline Value & $\begin{array}{l}\bullet \text { Intrinsic Goal Orientation } \\
\text { - Extrinsic Goal Orientation } \\
\bullet\end{array}$ & $\begin{array}{l}\text { Focus on learning and mastery } \\
\text { Focus on grades, rewards and evaluation by others } \\
\text { The student's evaluation of how interesting, } \\
\text { important and how useful the task is. }\end{array}$ \\
\hline Expectancy & $\begin{array}{l}\text { - Control of Learning Beliefs } \\
\text { Self-efficacy for learning and } \\
\text { performance }\end{array}$ & $\begin{array}{l}\text { The student's evaluation of his or her own efforts. } \\
\text { The student's belief that his or her efforts will result } \\
\text { in positive outcomes. }\end{array}$ \\
\hline Affective & $\bullet \quad$ Test Anxiety & Emotional reactions to a task \\
\hline
\end{tabular}

Table 2. Learning Strategies Scale

\begin{tabular}{|c|c|c|}
\hline COMPONENTS & FACTORS & \\
\hline \multirow{4}{*}{ 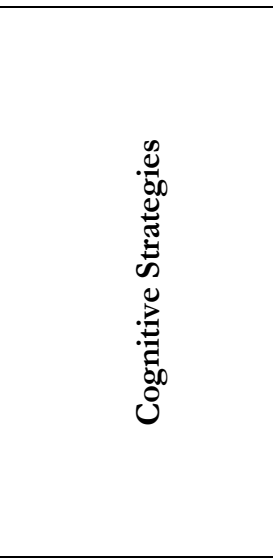 } & Rehearsal & $\begin{array}{l}\text { - Basic activity, mental repetition and learning through memorizing } \\
\text { - Used for learning by heart }\end{array}$ \\
\hline & Organization & $\begin{array}{l}\text { - Selecting appropriate information and constructing connections } \\
\text { in the information to be learned } \\
\text { - Clustering or classification, outlining, selecting the main idea and } \\
\text { so on }\end{array}$ \\
\hline & Elaboration & $\begin{array}{l}\text { - Helping learners store information in their long-term memory by } \\
\text { building internal connections between new information and prior } \\
\text { knowledge } \\
\text { - Paraphrasing, summarizing, creating analogies, note-taking and so } \\
\text { on }\end{array}$ \\
\hline & Critical thinking & $\begin{array}{l}\text { - Applying previous knowledge to new situations in order to solve } \\
\text { problems, reach decisions or make critical evaluations }\end{array}$ \\
\hline \multirow{3}{*}{ 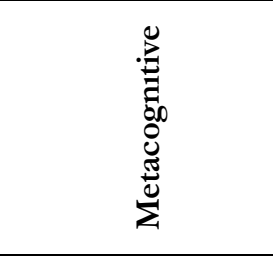 } & Planning & - Goal setting, task analysis \\
\hline & Monitoring & $\begin{array}{l}\text { - Tracking of one's attention as one reads, self-testing and } \\
\text { questioning }\end{array}$ \\
\hline & Regulating & $\begin{array}{l}\text { - Continuous adjustment of learners' cognitive activities to } \\
\text { improve performance by assisting them in checking and } \\
\text { correcting their behaviour }\end{array}$ \\
\hline \multirow{4}{*}{ 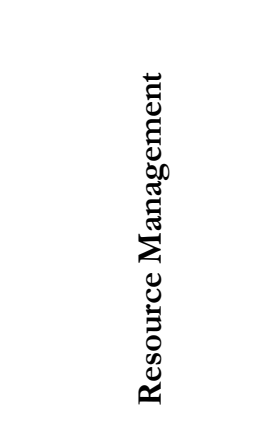 } & Help Seeking & $\begin{array}{l}\text { - Knowing when one does not know something and being able to } \\
\text { identify someone to assist }\end{array}$ \\
\hline & Peer Learning & - Learning through collaborating with one's peers \\
\hline & Effort Regulation & $\begin{array}{l}\text { - Ability to control one's effort and attention and a commitment } \\
\text { to completing one's study goals } \\
\text { - Continued use of learning strategies and goal commitment } \\
\text { despite distractions and finding the task uninteresting }\end{array}$ \\
\hline & $\begin{array}{l}\text { Time and } \\
\text { Environment }\end{array}$ & $\begin{array}{l}\text { - Scheduling, planning and managing one's study time } \\
\text { - Setting aside blocks of time to study, the effective use of that } \\
\text { study time, and setting realistic goals }\end{array}$ \\
\hline
\end{tabular}

Reference:Büyüköztürk, Ş., Akgün, Ö.E., Özkahveci, Ö.,Demirel F. (2004). The Validity and Reliability Study of the Turkish Version of the Motivated Strategies for Learning Questionnaire. Educational Sciences: Theory \& Practice. 4(2), 207-239.

Relating statements to themselves, individuals rate their level of agreement with each statement on a seven-point Likert scale from 'not at all true' (1) to 'completely true' (7). Consisting of two different sections and 15 scales, the MSLQ is modular and the scores on the scales can be used together or singly to fit the needs of the researcher or instructor. 
Keçeci, A. (2017). Self-regulated learning in nursing: A study from a health education course. Journal of Human Sciences, 14(4), 3830-3842. doi:10.14687/jhs.v14i4.4415

Data Analysis: Data were analysed using descriptive statistics such as frequency, percentage and mean, and the Mann-Whitney $U$ test, $t$-test and analysis of variance (ANOVA).

Ethical Considerations:The administration of the school of health where this study was conducted gave written permission for the study. And also it was get permission to use MSLQ by Büyüköztürk.

\section{RESULTS}

\section{Socio-demographic variables}

Of the participants in this study, $77.3 \%(\mathrm{n}=85)$ were female, $52.7 \%(\mathrm{n}=58)$ were in their third year of study, their academic achievement average was good level $(3.40 \pm 6.80), 42.7 \%(\mathrm{n}=$ 47) liked the school, $34.5 \%(\mathrm{n}=38)$ liked the Health Education course and $37.3 \%(\mathrm{n}=41)$ had neither positive nor negative opinions about the instructor.

\section{Levels of Motivation and Learning Strategies}

Students on the Health Education course received the highest scores on the extrinsic goal orientation scale of the motivation section (Table 3). This suggests that they tended to be motivated by external factors (e.g. approval by others, rewards). The highest scores were recorded on the elaboration scale of the learning strategies section. The most popular learning strategy for the students was storing information in their long-term memory by building internal connections between new information and prior knowledge, using techniques such as paraphrasing, summarizing, creating analogies and note-taking.

Table 3.Motivation Strategies for Learning Questionnaire Mean Scores

\begin{tabular}{|c|c|c|}
\hline & & $\mathrm{X} \pm \mathrm{SD}$ \\
\hline \multirow{6}{*}{ 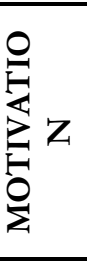 } & Intrinsic goal orientation & $4.40 \pm 1.19$ \\
\hline & Extrinsic goal orientation & $4.96 \pm 1.21$ \\
\hline & Task value & $4.49 \pm 1.16$ \\
\hline & Control belief about learning & $4.15 \pm 1.11$ \\
\hline & Self-efficacy for learning and performance & $4.72 \pm 1.02$ \\
\hline & Test anxiety & $3.02 \pm .95$ \\
\hline \multirow{9}{*}{ 兄 } & Rehearsal & $4.51 \pm 1.15$ \\
\hline & Organization & $4.55 \pm 1.30$ \\
\hline & Elaboration & $4.64 \pm 1.25$ \\
\hline & Critical thinking & $4.41 \pm 1.17$ \\
\hline & Help seeking & $4.31 \pm 1.16$ \\
\hline & Peer learning & $4.19 \pm 1.32$ \\
\hline & Metacognitive self-regulation & $4.44 \pm .91$ \\
\hline & Effort regulation & $4.23 \pm .79$ \\
\hline & Time and study environment & $4.42 \pm .82$ \\
\hline
\end{tabular}

Analysis of the scores on the MLSQ scales based on the gender variable showed that males scored significantly higher than females on the control of learning beliefs scale in the motivation section $(\mathrm{p}<0.05)($ Table 4). 
Keçeci, A. (2017). Self-regulated learning in nursing: A study from a health education course. Journal of Human Sciences, 14(4), 3830-3842. doi:10.14687/jhs.v14i4.4415

Table 4. Motivation Strategies Based on the Gender Variable

\begin{tabular}{|c|c|c|c|c|c|}
\hline & & Gender & $\mathrm{n}$ & $\mathrm{X} \pm \mathrm{SD}$ & $\mathrm{Z}_{\mathrm{MU}}, \mathrm{p}$ \\
\hline \multirow{2}{*}{ 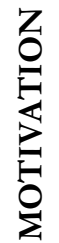 } & \multirow[b]{2}{*}{$\begin{array}{l}\text { Control of beliefs about } \\
\text { learning }\end{array}$} & Male & 25 & $4.68 \pm 1.21$ & \multirow{2}{*}{$\begin{array}{l}-2.814 \\
.005\end{array}$} \\
\hline & & Female & 85 & $3.99 \pm 1.04$ & \\
\hline
\end{tabular}

Based on the year-of-study variable, students' scores showed a significant difference between students in their third year and those in the second year on all the scales except for the test anxiety scale of the motivation section and the effort regulation scale of the learning strategies section $(p<0.05)$. This suggests that the students in their third year had a higher level of motivation than students in their second year and that the third-year students employed a variety of learning strategies (Table $5 \mathrm{i}$ and 5ii).

Table 5i. Motivation Strategies Based on the Year-of-Study Variable

\begin{tabular}{|c|c|c|c|c|c|}
\hline \multirow{13}{*}{ 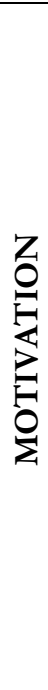 } & & $\begin{array}{ll}\text { YEAR } & \text { OF } \\
\text { STUDY } & \\
\end{array}$ & $\mathbf{N}$ & $\mathrm{X} \pm \mathrm{SD}$ & $t, p$ \\
\hline & \multirow{2}{*}{$\begin{array}{ll}\text { Intrinsic } & \text { goal } \\
\text { orientation } & \end{array}$} & Second Year & 52 & $3.94 \pm 1.12$ & \multirow{2}{*}{$\begin{array}{l}4.127 \\
0.000\end{array}$} \\
\hline & & Third Year & 58 & $4.82 \pm 1.10$ & \\
\hline & \multirow{2}{*}{$\begin{array}{ll}\text { Extrinsic } & \text { goal } \\
\text { orientation } & \end{array}$} & Second Year & 52 & $4.64 \pm 1.31$ & \multirow{2}{*}{$\begin{array}{l}2.708 \\
0.008\end{array}$} \\
\hline & & Third Year & 58 & $5.24 \pm 1.04$ & \\
\hline & \multirow[t]{2}{*}{ Task value } & Second Year & 52 & $4.05 \pm 1.09$ & \multirow{2}{*}{$\begin{array}{l}4.126 \\
0.000\end{array}$} \\
\hline & & Third Year & 58 & $4.90 \pm 1.07$ & \\
\hline & \multirow{2}{*}{$\begin{array}{l}\text { Control of beliefs } \\
\text { about learning }\end{array}$} & Second Year & 52 & $3.86 \pm 1.14$ & \multirow{2}{*}{$\begin{array}{l}2.653 \\
0.009\end{array}$} \\
\hline & & Third Year & 58 & $4.41 \pm 1.03$ & \\
\hline & \multirow{2}{*}{$\begin{array}{lr}\text { Self-efficacy } & \text { for } \\
\text { learning } & \text { and } \\
\text { performance } & \end{array}$} & Second Year & 52 & $4.49 \pm 1.06$ & \multirow{2}{*}{$\begin{array}{l}2.283 \\
0.024\end{array}$} \\
\hline & & Third Year & 58 & $4.93 \pm .95$ & \\
\hline & \multirow[t]{2}{*}{ Test anxiety } & Second Year & 52 & $2.85 \pm .78$ & \multirow{2}{*}{$\begin{array}{l}1.772 \\
0.079\end{array}$} \\
\hline & & Third Year & 58 & $3.17 \pm 1.07$ & \\
\hline
\end{tabular}

Table 5ii. Learning Strategies Based on the Year-of-Study Variable

\begin{tabular}{|c|c|c|c|c|c|}
\hline \multirow{17}{*}{ 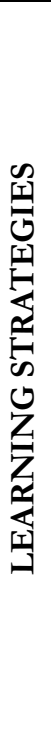 } & & $\begin{array}{ll}\text { YEAR } & \text { OF } \\
\text { STUDY } & \\
\end{array}$ & $\mathbf{N}$ & $\mathrm{X} \pm \mathrm{SD}$ & $t, p$ \\
\hline & \multirow[t]{2}{*}{ Rehearsal } & Second Year & 52 & $4.14 \pm 1.16$ & 3.376 \\
\hline & & Third Year & 58 & $4.85 \pm 1.05$ & 0.001 \\
\hline & \multirow[t]{2}{*}{ Organization } & Second Year & 52 & $4.05 \pm 1.32$ & 4.053 \\
\hline & & Third Year & 58 & $5.00 \pm 1.12$ & 0.000 \\
\hline & \multirow[t]{2}{*}{ Elaboration } & Second Year & 52 & $4.13 \pm 1.34$ & 4.391 \\
\hline & & Third Year & 58 & $5.11 \pm .94$ & 0.000 \\
\hline & \multirow[t]{2}{*}{ Critical thinking } & Second Year & 52 & $4.00 \pm 1.24$ & 3.688 \\
\hline & & Third Year & 58 & $4.78 \pm .97$ & .000 \\
\hline & \multirow[t]{2}{*}{ Help seeking } & Second Year & 52 & $3.89 \pm 1.30$ & 3.825 \\
\hline & & Third Year & 58 & $4.69 \pm .86$ & 0.000 \\
\hline & \multirow[t]{2}{*}{ Peer learning } & Second Year & 52 & $3.83 \pm 1.17$ & 2.716 \\
\hline & & Third Year & 58 & $4.50 \pm 1.38$ & 0.008 \\
\hline & \multirow{2}{*}{$\begin{array}{l}\text { Metacognitive self- } \\
\text { regulation }\end{array}$} & Second Year & 52 & $4.09 \pm 1.05$ & 4.145 \\
\hline & & Third Year & 58 & $4.76 \pm .62$ & 0.000 \\
\hline & \multirow{2}{*}{$\begin{array}{l}\text { Time and study } \\
\text { environment }\end{array}$} & Second Year & 52 & $4.13 \pm .91$ & 3.705 \\
\hline & & Third Year & 58 & $4.68 \pm .64$ & 0.000 \\
\hline
\end{tabular}


Analysis of students' scores in the motivation section of the Motivated Strategies for Learning Questionnaire in relation to attitudes towards the school showed a significant difference among students who liked the school compared with those who did not, on the intrinsic goal orientation, task value and self-efficacy for learning and performance scales $(p<0.05)$ (Table 6 i). This suggests that the students who liked the school had a higher level of intrinsic responsibility and commitment to a task and, therefore, a higher level of self-efficacy. Similarly, on the organization, critical thinking and metacognitive self-regulation scales of the learning strategies section, there was again a significant difference among students who liked their school compared with those who did not $(\mathrm{p}<0.05)$ (Table 6 ii). Thus, it may be suggested that students who reportedly liked their school employed learning strategies more often than students who did not.

Analysis of the students' scores on the scales in the motivation section in relation to attitudes towards the course showed a significant positive difference between students who liked the course and those who did not, on the intrinsic goal orientation, task value, control of learning beliefs and self-efficacy for learning and performance scales $(p<0.05)$. Similarly, on the rehearsal, organization, elaboration, critical thinking, peer learning, and metacognitive self-regulation scales in the learning strategies section, there was again a significant positive difference between students who liked the school and those who did not $(\mathrm{p}<0.05)$.

Finally, students' scores on the scales in the motivation section in relation to attitudes towards the instructor showed a significant positive difference between students who liked the instructor and those who did not, on the task value and control of learning beliefs scales $(p<0.05)$. Similarly, on the rehearsal and elaboration scales in the learning strategies section, the scores of students who liked the instructor showed a significant positive difference compared with those who $\operatorname{did} \operatorname{not}(\mathrm{p}<0.05)$. 
Keçeci, A. (2017). Self-regulated learning in nursing: A study from a health education course. Journal of Human Sciences, 14(4), 3830-3842. doi:10.14687/jhs.v14i4.4415

Table 6 (i). Motivation Strategies Based on Attitudes towards the School, the Course and the Instructor ${ }^{2}$

\begin{tabular}{|c|c|c|c|c|c|}
\hline \multirow{14}{*}{ 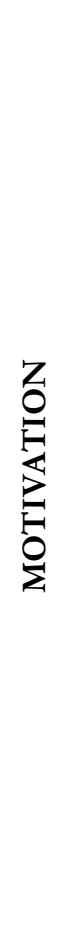 } & & Variables & School & Course & Instructor \\
\hline & & & $\mathrm{X} \pm \mathrm{SD}$ & $\mathrm{X} \pm \mathrm{SD}$ & $\mathrm{X} \pm \mathrm{SD}$ \\
\hline & \multirow{3}{*}{$\begin{array}{l}\text { Intrinsic } \\
\text { orientation }\end{array}$} & Like & $4.74 \pm 1.13$ & $5.07 \pm 1.19$ & ---- \\
\hline & & $\begin{array}{l}\text { Neither like nor } \\
\text { dislike }\end{array}$ & $4.48 \pm 1.10$ & $4.23 \pm 0.99$ & --- \\
\hline & & Dislike & $3.83 \pm 1.17$ & $3.90 \pm 1.04$ & ---- \\
\hline & \multirow[t]{3}{*}{ Task value } & Like & $4.80 \pm 1.23$ & $5.41 \pm 0.82$ & $5.26+1.10$ \\
\hline & & $\begin{array}{l}\text { Neither like nor } \\
\text { dislike }\end{array}$ & $4.50 \pm 0.94$ & $4.14 \pm 0.97$ & $4.26 \pm 1.07$ \\
\hline & & Dislike & $4.04 \pm 1.12$ & $3.91 \pm 1.05$ & $4.20 \pm 1.07$ \\
\hline & \multirow{3}{*}{$\begin{array}{l}\text { Control of learning } \\
\text { beliefs }\end{array}$} & Like & ---- & $4.74+1.07$ & $4.71+1.25$ \\
\hline & & $\begin{array}{lll}\begin{array}{l}\text { Neither } \\
\text { dislike }\end{array} & \text { like nor } \\
\end{array}$ & $\begin{array}{ll}--- \\
--\end{array}$ & $3.88 \pm 1.04$ & $4.06 \pm 1.05$ \\
\hline & & Dislike & ---- & $3.81 \pm 1.00$ & $3.85 \pm 0.95$ \\
\hline & \multirow{3}{*}{$\begin{array}{lr}\text { Self-efficacy } & \text { for } \\
\text { learning } & \text { and } \\
\text { performance } & \end{array}$} & Like & $5.02 \pm 1.00$ & $5.14 \pm 0.98$ & $\begin{array}{ll}--- \\
-\end{array}$ \\
\hline & & $\begin{array}{l}\text { Neither like nor } \\
\text { dislike }\end{array}$ & $4.69 \pm 0.93$ & $4.48 \pm 1.03$ & $\begin{array}{ll}--- \\
--\end{array}$ \\
\hline & & Dislike & $4.32 \pm 1.04$ & $4.53 \pm 0.96$ & ---- \\
\hline
\end{tabular}

${ }^{2}$ Only variables with significant differences and their mean scores are presented here. 
Keçeci, A. (2017). Self-regulated learning in nursing: A study from a health education course. Journal of Human Sciences, 14(4), 3830-3842. doi:10.14687/jhs.v14i4.4415

Table 6 (ii). Learning Strategies Based on Attitudes towards the School, the Course and the Instructor ${ }^{3}$

\begin{tabular}{|c|c|c|c|c|c|}
\hline \multirow{21}{*}{ 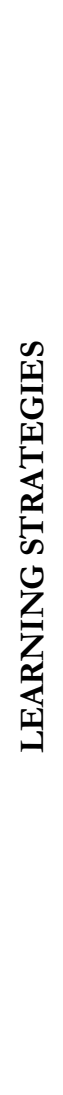 } & & \multirow[t]{2}{*}{ Variables } & School & Course & Instructor \\
\hline & & & $\mathrm{X} \pm \mathrm{SD}$ & $\mathrm{X} \pm \mathrm{SD}$ & $\mathrm{X} \pm \mathrm{SD}$ \\
\hline & \multirow[t]{3}{*}{ Rehearsal } & Like & ---- & $4.92 \pm 1.12$ & $4.98 \pm 1.02$ \\
\hline & & Neither like nor dislike & $\begin{array}{ll}--- \\
\end{array}$ & $4.30 \pm 1.28$ & $4.39 \pm 1.13$ \\
\hline & & Dislike & $\begin{array}{ll}--- \\
\end{array}$ & $4.29 \pm 0.98$ & $4.31 \pm 1.19$ \\
\hline & \multirow[t]{3}{*}{ Organization } & Like & $5.00 \pm 1.41$ & $4.99 \pm 1.29$ & ---- \\
\hline & & Neither like nor dislike & $4.34 \pm \mathbf{0 . 9 1}$ & $4.37 \pm 1.33$ & ---- \\
\hline & & Dislike & $4.10 \pm 1.28$ & $4.28 \pm 1.21$ & ---- \\
\hline & \multirow{3}{*}{ Elaboration } & Like & ---- & $5.25 \pm 1.10$ & $5.23 \pm 1.21$ \\
\hline & & Neither like nor dislike & --- & $4.40 \pm 1.27$ & $4.43 \pm 1.19$ \\
\hline & & Dislike & $\begin{array}{c}--- \\
\end{array}$ & $4.26 \pm 1.16$ & $4.45 \pm 1.22$ \\
\hline & \multirow{4}{*}{$\begin{array}{l}\text { Critical } \\
\text { thinking }\end{array}$} & Like & $4.73 \pm 1.29$ & $5.02 \pm 1.16$ & --- \\
\hline & & Neither like nor dislike & $4.41 \pm 1.03$ & $4.02 \pm 1.02$ & --- \\
\hline & & Dislike & $3.94 \pm 0.96$ & $4.15 \pm 1.08$ & ---- \\
\hline & & & & & \\
\hline & \multirow{3}{*}{$\begin{array}{l}\text { Metacognitive } \\
\text { self-regulation }\end{array}$} & Like & $4.63 \pm 1.01$ & $4.74 \pm 0.79$ & $\begin{array}{ll}--- \\
\end{array}$ \\
\hline & & Neither like nor dislike & $4.60 \pm 0.78$ & $4.33 \pm 1.01$ & ---- \\
\hline & & Dislike & $4.01 \pm \mathbf{0 . 7 4}$ & $4.25 \pm 0.88$ & ---- \\
\hline & \multirow[t]{3}{*}{ Peer learning } & Like & $\begin{array}{ll}--- \\
\end{array}$ & $4.62 \pm 1.26$ & ---- \\
\hline & & Neither like nor dislike & $\begin{array}{ll}--- \\
\end{array}$ & $3.97 \pm 1.31$ & --- \\
\hline & & Dislike & $\begin{array}{ll}--- \\
\end{array}$ & $3.94 \pm 1.31$ & --- \\
\hline
\end{tabular}

${ }^{3}$ Only variables with significant differences are presented here because there were too many different criteria and comparisons. 
Keçeci, A. (2017). Self-regulated learning in nursing: A study from a health education course. Journal of Human Sciences, 14(4), 3830-3842. doi:10.14687/jhs.v14i4.4415

Analysis of the students' scores in the motivation section of the MSLQ with respect to their academic achievement showed that there was only a slightly positive correlation between academic achievement and the control of learning beliefs $(r=0.196, p=0.047)$.

\section{DISCUSSION}

The results of this study included the motivation and learning strategies and self-regulation behaviours of students in their second and third year of study on a Health Education course.

The principal type of motivation that the students had with regard to the Health Education course was found to be extrinsic goal orientation, which was associated with students' satisfaction, values and the desire to get higher grades than others (Turan et al. 2011). In their research, Salamonson et al. (2009) and Puteh and Ibrahim (2010) found a similarly high level of extrinsic goal orientation. On the other hand, Sungur and Tekkaya (2010) found that the extrinsic goal orientation scale scores were higher before the students engaged in problem-based learning, whereas the task value and control of learning beliefs scales scores were higher following the implementation of the learning method.

Motivation is the basis for self-regulatory skills. Motivated students can effectively regulate their own learning by accepting responsibility for it. Nevertheless, for an effective use of learning strategies, extrinsic motivation needs to be developed first and then knowledge, skills and attitudes should gradually be transformed into internal motivation. Naturally, teachers play a key role in this process (Vavrova et al. 2012). Motivation is an important factor in activating and maintaining behaviour in self-regulated learning. Students' opinions and beliefs about the reason why they are required to complete a certain activity and the level of effort they need to perform that activity play an important role in the formation of their behaviour. If students do not see learning objectives as valuable or feel adequately equipped to meet those objectives, formation of the appropriate behaviour will be difficult (Zumbrunn, Tadlock and Roberts 2011). In the light of these findings, it seems that the instructor in our study activated the students' extrinsic motivation but the students did not fully comprehend the outcomes. In line with the findings reported by Sungur and Tekkaya (2010), the students enrolled in the Health Education course could participate more actively in the teaching and learning process by using methods such as problem-based learning and active learning, which could enhance their intrinsic goal orientation.

Of the learning strategies, the one that students in our study employed most was the elaboration strategy. This involves storing information in the long-term memory by building internal connections between new information and prior knowledge, using learning techniques such as paraphrasing, summarizing, creating analogies and note-taking. Mahmodi et al. (2014) and Artino Jr. and Stephens (2009) similarly reported that learning strategies that connected prior knowledge with new knowledge were preferred to other strategies. Petuh and Ibrahim (2010), however, found that the regulation of time and the study environment was the most favoured among other learning strategies. Research conducted in Turkey also suggested different conclusions. According to these studies, the most popular learning strategies among students were metacognitive self-regulation and regulation of time and the study environment (Sağırlı and Azapağası 2009); problem-based learning, increasing students' use of elaboration, critical thinking, metacognitive self-regulation, effort regulation and peer learning (Sungur and Tekkaya 2010); strategies based on rehearsal (Vural 2011); metacognitive learning strategies in the field of health sciences (Ozan et al. 2012); and rehearsal, organization and elaboration (Karataş et al. 2014). 
Keçeci, A. (2017). Self-regulated learning in nursing: A study from a health education course. Journal of Human Sciences, 14(4), 3830-3842. doi:10.14687/jhs.v14i4.4415

These findings suggest that different groups of students prefer different learning strategies. On the other hand, a preference for the elaboration strategy, which allows students to make interpretations, may be considered a positive outcome, but we also recommend a revision of the syllabus of the Health Education course in such a way as to ensure more frequent use of other learning strategies as well. The least popular learning strategy used by students in both the second and third year of study was peer learning. Similarly, Salamonson et al. (2009) found that the learning strategy employed least often by nursing students was peer learning. In the Health Education course, this result could be attributed to the lack of time allocated for group activities to support peer learning, although it could also be explained by the increasing individualization of the present day, which isolates individuals from internal groups. People with an individualistic approach see their own agendas as being more important than the goals of their group, and they tend to demonstrate behaviours based on individual risk-benefit analysis, under the influence of a predominantly competitive social structure. In contrast with the 'collectivist' tenor of Turkish society, there appears to have been a rapid rise in individualism, particularly among the welleducated and the young in urban areas (Kağıtçıbaşı 2005). The declining use of peer collaboration as a learning strategy among nursing students in this study can be considered a reflection of a changing social structure.

Students' scores in the motivation section of our survey revealed a significant difference between male and female students on the control of learning beliefs scale $(p<0.05$, Table 4$)$, meaning that the male students had a higher level of control of learning beliefs than the females. This belief refers to students' trust in the capacity of their own efforts, rather than external factors, to yield positive learning outcomes (Turan et al. 2011). Thus, the male students in our study appeared to believe more strongly than the female students that they should strive for success. However, the effect of gender on self-regulation behaviour is a controversial issue and there are conflicting findings on this issue. Fettahlioğlu (2011), for instance, reported that male students used all learning strategies more often than female students but the difference was not significant. Sahin (2010) reported that female students scored significantly higher than males on motivation and selfregulation behaviors. İflazoğlu and Tümkaya (2008) argued that female students tended to have a higher level of motivation than male students. The study by Karataş et al. (2014) with university students reported that gender did not have any significant effect on motivation. The variability among these findings indicates the need for more evidence on the effect of gender on selfregulation behaviours.

Scores in the present study showed a significant positive difference between students in their third year and those in the second year on all scales except for the test anxiety scale in the motivation section and the effort regulation scale in the learning strategies section $(p<0.05$, Table 5i-ii). Students in the third year thus had a higher level of motivation than students in the second year, and the third-year students employed a variety of learning strategies. Sağırlı et al. (2010), on the other hand, reported a decrease in the level of motivation in later years of study. The lack of a significant difference between the students in their second and third years of study on the test anxiety and effort regulation scales could be attributed either to the fact that neither of the groups suffered from test anxiety or to the fact that they had similar levels of test anxiety and had similar feelings and thoughts about maintaining not only the effort required but also sustained attention in the face of obstacles that arise in the learning process.

In the motivation section, students who liked the school scored significantly higher on the intrinsic goal orientation, task value and self-efficacy for learning and performance scales than those who did not $(\mathrm{p}<0.05$, Table 6i). Thus, students who liked the school felt a higher level of intrinsic responsibility for the course; they tended to find the course content more interesting, useful and 
Keçeci, A. (2017). Self-regulated learning in nursing: A study from a health education course. Journal of Human Sciences, 14(4), 3830-3842. doi:10.14687/jhs.v14i4.4415

important and therefore they had a higher level of self-efficacy. This result could be attributed to the social judgment theory, which suggests that, the higher the level of personal involvement, the greater is the scope of rejection. That is, individuals with higher ego involvement are more likely to reject opposing potentials. By the same token, the lower the level of personal involvement, the greater is the latitude of acceptance (Kağıtçıbaş1 2005). Thus, students who reported that they liked the school or who had positive attitudes towards the school and were committed to this opinion were committed to all courses in general and were personally involved in the Health Education course in particular. Social judgment theory also asserts that if an individual associates a totally new object with another object towards which he or she already has an attitude or position, assimilation will occur and the original attitude will be transferred to the new object (Kağıtçıbaş1 2005). When liking the school is considered to be the pre-existing attitude, the original position, that of liking the Health Education course and being more motivated towards it, could be regarded as an expected outcome. In addition, the students' positive attitudes may have caused them to feel more personally involved in the course, which in turn may have encouraged them to claim more individual responsibility.

Similarly, on the organization, critical thinking, and metacognitive self-regulation scales of the learning strategies section, students who liked the school again scored significantly more highly than those who did not $(\mathrm{p}<0.05$, Table 6ii). Students who liked the school seemed to develop and implement skills such as establishing connections between their prior and new learning experiences, conducting critical evaluations, setting goals and performing necessary revisions by constantly monitoring their own performance.

In terms of motivation, students who liked the course scored more highly on the intrinsic goal orientation, task value, control of learning beliefs and self-efficacy for learning and performance scales than those who did not $(p<0.05$, Table 6i). Thus, students who liked the course felt a higher personal involvement in learning; they tended to find the course content more interesting, useful and important and therefore they had a higher level of self-efficacy, more frequently employing individual control and intrinsic motivation. In fact, if extrinsic goal orientation and test anxiety are regarded as external sources of motivation, it is only to be expected that there was no significant difference on these scales.

Similarly, on the rehearsal, organization, elaboration, critical thinking, peer learning and metacognitive self-regulation scales of the learning strategies section, students who liked the school registered significantly higher scores $(\mathrm{p}<0.05$, Table 6ii). These students employed learning strategies such as mental rehearsal and memorization, establishing connections between their prior and new learning experiences, carrying out interpretations and critical evaluations, peer learning and performing necessary revisions by constantly monitoring their own performance in accordance with their learning goals. In general, therefore, the students who reported that they liked the course used cognitive and metacognitive learning strategies more frequently than those who did not, but they used and cared about resource management strategies less often. This result is consistent with another finding of the present study, that the students who liked the course tended to employ intrinsic types of motivation. Given that the level of motivation is a powerful activator of students' learning strategies (Kelecioğlu 1992), it may be suggested that intrinsic types of motivation will probably increase the frequency of the use of cognitive and metacognitive strategies that generally indicate internal processes.

Students who liked the instructor registered significantly higher scores on the task value and control of learning beliefs scales than those who did not $(\mathrm{p}<0.05)$. Students who liked the instructor also tended to find the course content more interesting, useful and important; they felt a 
Keçeci, A. (2017). Self-regulated learning in nursing: A study from a health education course. Journal of Human Sciences, 14(4), 3830-3842. doi:10.14687/ihs.v14i4.4415

higher personal involvement in learning and believed that their efforts would yield positive outcomes.

Similarly, on the rehearsal and elaboration scales of the learning strategies section, students who liked the instructor again scored significantly more highly than those who did not $(\mathrm{p}<0.05)$. The students who liked the instructor seemed to employ learning strategies such as rehearsal, making interpretations and trying to store knowledge in their long-term memory for longer durations of time and more frequently than students who reportedly did not like the instructor.

Analysis of the students' scores on the scales of the MSLQ with respect to their academic achievement showed that there was only a slightly positive correlation between academic achievement and the control of learning beliefs scale in the motivation section $(\mathrm{r}=0.196, \mathrm{p}=$ 0.047). Broadbent and Poon (2015) found a slightly positive correlation between online learners' academic achievement and the metacognitive self-regulation, time management, critical thinking and effort regulation scales. Şahin (2010), however, reported that there was no relationship between academic achievement and self-regulation skills. Iflazoğlu and Tümkaya (2008) found that students with higher levels of academic achievement recorded significantly higher scores on the test anxiety scale. Although our study suggests that students tended to have more positive perceptions of success as their level of academic achievement increased, there still seems to be a need for future research to provide more detailed data on the subject.

Limitations: The study is limited to the students enrolled in the particular Health Education course offered and to their responses.

\section{CONCLUSION}

Nursing students were found, overall, to be motivated by extrinsic factors, but students who liked the course and the school were additionally motivated by intrinsic factors. They preferred the elaboration learning strategy, which involves storing information in the long-term memory by building internal connections between new information and prior knowledge, using learning techniques such as paraphrasing, summarizing, creating analogies and note-taking. However, students on the Health Education course who liked the nursing faculty preferred responsibility and task value over other strategies.

\section{REFERENCES}

Altun,S., Erden, M.(2006). Validity and reliability study of the dimensions 'Motivated Strategies for Learning Questionnaire'. Edu 7, 2(1), 1-16.

Artino Jr., A., Stephens, J.M.(2009). Academic motivation and self-regulation: A comparative analysis undergraduate and graduate students learning online. Internet and Higher Education, 12(3), 146151.

Broadbent, J., Poon, W.L.(2015). Self-regulated learning strategies and academic achievement in online higher education learning environments: A systematic review. Internet and Higher Education, 27, 1-13. http://dx.doi.org/10.1016/i.iheduc.2015.04.007.

Büyüköztürk, Ş., Akgün, Ö.E., Özkahveci, Ö.,Demirel F.(2004). The Validity and Reliability Study of the Turkish version of the motivated strategies for Learning Questionnaire. Educational Sciences: Theory and Practice, 4(2), 207-239.

Cleary, T.J., Zimmerman, B.J(2004). Self-regulation empowerment program: A school-based program to enhance self-regulated and self-motivated cycles of student learning. Psychology in the Schools, 41(5), 537-550. 
Keçeci, A. (2017). Self-regulated learning in nursing: A study from a health education course. Journal of Human Sciences, 14(4), 3830-3842. doi:10.14687/jhs.v14i4.4415

Fettahlioğlu, P.(2011). The analysis of using self-regulated learning strategies according to gender factor. Procedia Social and Behavioral Sciences, 15, 2748-2752.

Iflazoğlu, A. Tümkaya, S.( 2008). An investigation of the relationship between student teachers' motivation levels and their academic achievement of educational drama. PamukkaleÜniversitesi Journal of Faculty of Education, 1(23), 61-73.

Kağitçibaşi, C.. 2005. YeniInsanveİnsanlar. (10 th Edition)( Evrim Publishing, İstanbul).

Karataş, S., Güleş, H., Aypay, A. (2014). University students' motivation levels towards learning and learning strategies they use. Journal of Educational Policy Analysis, 3(2), 31-48.

Kelecioğlu, H( 1992). Motivation. Hacettepe University Journal of Education, 7, 175-181.

Mahmodi, M.H., Kalantari, B., Ghaslani, R(2014). Self-regulated learning (SRL), motivation and language achievement of Iranian EFL learners. Procedia-Social and Behavioral Sciences, 98, 10621068.

Montolvo, F. T., Torres, M.C. G.(2004). Self-regulated learning: Current and future directions. Electronic Journal of Research in Educational Psychology 2(1), 1-34.

Ozan, C., Gündoğdu, K., Bay, E., Celkan, H. Y. (2012). A study on the university students' selfregulated learning strategies skills and self-efficacy perceptions in term of different variables. Procedia-Social and Behavioral Sciences, 46, 1806-1811.

Pintrich, P.R., Smith, D.A.F., Garcia, T. \&Mckeachie, W.J.(1991). A Manual for the use of the motivated strategies for learning (Michigan: School of Education Building, The University of Michigan).

Pintrich, D.G.(1990). Motivational and Self-Regulated Learning Components of Classroom Academic Performance. Journal of Educational Psychology, 82(1), 33-40.

Puteh, M., Ibrahim, M.(2010). The usage of self-regulated learning strategies among form four students in the mathematical problem-solving context: A case study. Procedia Social and Behavioral Sciences, $8,446-452$.

Sağirli, M.Ö., Azapağasi, E.(2009). Investigation of self-regulated learning disabilities of college students. Ankara University Journal of Faculty of Educational Sciences, 42(2), 129-161.

Salamonson, Y., Everett, B., Koch, J., Wilson, I., Davidson, P.M.(2009). Learning strategies of first year nursing and medical students: A comparative study. International Journal of Nursing Studies, 46(12), 1541-1547.

Sari, A., Akinoğlu. O (2009). Self-regulated learning: models and applications. Marmara University Journal of Educational Sciences, 29, 139-154.

Sungur, S.,Tekkaya, C.(2010). Effects of problem-based learning and traditional instruction on selfregulated learning. The Journal of Educational Research, 99(5), 307-320.

Şahin, S.M(2010). The relation between self regulation skills and academic achievement of preservice elementary teachers in mathematics teaching courses. E-Journal of New World Sciences Academy, 5(3), 1370-1381.

Sardareh, S.A, Saad, M.R.M., Boroomand, R.(2012). Self-Regulated Learning Strategies (SRLS) and academic achievement in pre-university EFL learners. California Linguistic Notes, 37(1), 1-35.

Song, L., Hill, J.R.(2007). A Conceptual Model for Understanding Self-Directed Learning in Online Environments. Journal of Interactive Online Learning, 6(1), 27-42.

Turan, S., Üner, S., Elçin, M. (2011). The impact of standardized patient feedback on student motivational levels. Balkean Medical Journal , 28, 43-48.

Vavrova, S., Hladik, J., Hrbackova, K.(2012). The Determinants of Self-Regulated Learning Development in Students of Helping Professions. Procedia - Social and Behavioral Sciences, 69 (1), $332-340$.

Vural, L.(2011). The learning problems that the pre-service teachers faced intheir studies and their learning strategies. Dicle University Journal of Ziya Gökalp Faculty of Education, 16, 46-65.

Zimmerman, B. J.(1990). Self-regulated learning and academic achievement: An overview. Educational Psychologist, 25(1), 3-17.

Zumbrunn, S., Tadlock, J., Roberts, E.D.(2011). Encouraging Self-Regulated Learning in the Classroom: A Review of the Literature (Metropolitan Educational Research Consortium (MERC), Virginia Commonwealth University). 